\title{
COMPUTER MODELING OF NONLINEAR SYSTEM VIBRATIONS WITH APPLOWANCE FOR NONLOCAL DAMPING
}

\author{
Vadim D. Potapov, Elena S. Shepitko \\ Russian University of Transport (MIIT), Moscow, RUSSIA
}

\begin{abstract}
The paper is devoted to the analysis of the nonlocal damping consideration influence on the results of computer modeling of nonlinear systems subjected to periodic deterministic and stochastic stationary loads forced vibrations The shallow arc dynamic behavior is examined. The Galerkin method is used for the problem solving.
\end{abstract}

Keywords: computer modeling, nonlinear systems vibrations, nonlocal damping, Galerkin method, deterministic periodic load, stochastic stationary load

\section{МОДЕЛИРОВАНИЕ КОЛЕБАНИЙ НЕЛИНЕЙНЫХ СИСТЕМ С УЧЁТОМ НЕЛОКАЛЬНОГО ДЕМПФИРОВАНИЯ}

\author{
В.Д. Потапов, Е.С. Шепитько \\ Российский университет транспорта (МИИТ), г. Москва, РОССИЯ
}

\begin{abstract}
: Статья посвящена анализу влияния учёта нелокального демпфирования на результаты компьютерного моделирования вынужденных колебаний нелинейной системы под действием детерминированной периодической и стохастической стационарной нагрузки. Динамическое поведение системы исследуется на примере пологой арки. Для решения задачи используется метод БубноваГалёркина.
\end{abstract}

\begin{abstract}
Ключевые слова: компьютерное моделирование, колебания нелинейных систем, нелокальное демпфирование, метод Бубнова-Галёркина, детерминированная периодическая нагрузка, стохастическая стационарная нагрузка.
\end{abstract}

\section{INTRODUCTION}

The engineering structures are subjected to various external dynamic loads such as seismic loads, wind loads, transport loads, pedestrian loads, etc. It is important to take the vibration energy dissipation into account for the structures design process. The damping model choice is highly correlated to the precision of calculations especially for the structures that are made of modern composite materials. Using the damping models that are closer to reality allows to decrease the risks for such structures

Damping in the certain point of the structure with longitudinal coordinate $\mathrm{x}_{1}$, obviously depends not only on local value of motion velocity at this point $\mathrm{v}\left(\mathrm{x}_{1}\right)$, but also on the values of motion velocity in the neighboring points. The more distance between the two points the lower influence one of them on another [2].

The modern structures often contain geometrically nonlinear elements. Moreover, under external impacts the certain linear elements may change the shape and acquire some nonlinear features. In this research the problem of nonlinear system forced vibrations modeling consider nonlocal damping solved. As an example of the nonlinear system the shallow arc is used. Nonlocal damping modal is assumed consider the time hysteresis effect that was proposed in paper [2]. 
Shallow arc dynamic process has some specific features such as deflection leap under some loads. [TU] To determine the load range that allows to fully analyze all dynamic regimes of shallow arc the static loading is used.

The numerical solution of the problem and study of the shallow arc vibrations modeling consider nonlocal damping results are given in the paper. Shallow arc motion is modelled under the periodic deterministic and stationary stochastic transverse load.

\section{PROBLEM STATEMENT}

To describe the damping process the KelvinVoigt material model is commonly used in engineering practice:

$$
\sigma=\mathrm{E} \varepsilon+\gamma \mathrm{E} \dot{\varepsilon},
$$

where $\sigma, \varepsilon$ - normal stress and axial strain, $\dot{\varepsilon}-$ rate of strain change, $\mathrm{E}-$ Young modulus, $\gamma-$ damping ratio.

In the paper the dot indicates the time derivative.

Consider nonlocal damping equation transforms to [2]:

$$
\begin{gathered}
\sigma(\mathrm{x}, \mathrm{t})=\underset{\mathrm{l}}{\mathrm{E}}[\varepsilon(\mathrm{x}, \mathrm{t}) \\
+\gamma \int_{0}^{1} \mathrm{C}_{\mathrm{v}}(\mid \mathrm{x} \\
-\theta \mid) \dot{\varepsilon}(\theta, \mathrm{t}) \mathrm{d} \theta]
\end{gathered}
$$

Here $C_{v}(|x-\theta|)$ - the kernel function, which characterize the nonlocal. The $\mathrm{C}_{\mathrm{v}}(|\mathrm{x}-\theta|)$ function responds to normalization requirement, that is:

$$
\int_{-\infty}^{\infty} C_{v}(|x-\theta|) d \theta=1
$$

In the paper the exponential kernel function is used:

$$
C_{v}(|x-\theta|)=\frac{\mu}{2} \cdot e^{-\mu|x-\theta|}
$$

Here $\mu$ is the parameter that characterize the influence distance of the nonlocal damping model , $x, \theta$ are the longitudinal coordinate.

The equilibrium equation for the elementary shallow arc piece is:

$$
\begin{aligned}
& \frac{\partial^{2} \mathrm{M}(\mathrm{x}, \mathrm{t})}{\partial \mathrm{x}^{2}}=\mathrm{m} \frac{\partial^{2} \mathrm{w}(\mathrm{x}, \mathrm{t})}{\partial \mathrm{t}^{2}} \\
&-\mathrm{N}\left[\frac{\partial^{2} \mathrm{w}(\mathrm{t}, \mathrm{x})}{\partial \mathrm{x}^{2}}+\frac{1}{\mathrm{R}}\right] \\
&-\mathrm{q}(\mathrm{x}, \mathrm{t}) .
\end{aligned}
$$

Here $\mathrm{w}(\mathrm{x}, \mathrm{t})$-arc deflection, $\mathrm{m}$ - linear mass, $\mathrm{q}(\mathrm{x}, \mathrm{t})$ - transverse distributed load, $\mathrm{R}$ - radius of arc curvature, $\mathrm{N}$ - longitudinal internal force. Neglecting the longitudinal vibrations of arc the longitudinal force could be determined as:

$$
\mathrm{N}(\mathrm{t}, \mathrm{x})=\mathrm{EA}^{0}(\mathrm{x}, \mathrm{t}),
$$

where $A-\operatorname{arc}$ cross section area, a $\varepsilon^{0}(x, t)-$ longitudinal axial strain, which is determined as:

$$
\begin{gathered}
\varepsilon^{0}(\mathrm{x}, \mathrm{t})=\frac{\partial \mathrm{u}(\mathrm{t}, \mathrm{x})}{\partial \mathrm{x}}+\frac{1}{2}\left[\frac{\partial \mathrm{w}(\mathrm{t}, \mathrm{x})}{\partial \mathrm{x}}\right]^{2} \\
-\frac{\mathrm{w}(\mathrm{t}, \mathrm{x})}{\mathrm{R}},
\end{gathered}
$$

where $\mathrm{u}(\mathrm{t}, \mathrm{x})$ - arc axis displacement The moment expression is:

$$
\begin{aligned}
M(x, t)=E I & \frac{\partial^{2} w(x, t)}{\partial t^{2}} \\
& +\gamma \int_{0}^{1} C_{v}(\mid x \\
& \left.-\theta \mid) \frac{\partial^{3} w(\theta, t)}{\partial \theta^{2}} \partial \operatorname{td} \theta\right]
\end{aligned}
$$


where EI - arc bending stiffness.

Substitute the second derivative of the moment expression to the left part of the equation (5), and obtain the expression regarding the deflection function $\mathrm{w}(\theta, \mathrm{t})$ :

$$
\begin{aligned}
\frac{\partial^{2} w(x, t)}{\partial t^{2}} & +\frac{E I}{m}\left[\frac{\partial^{4} w(x, t)}{\partial x^{4}}\right. \\
& +\gamma \frac{\partial^{2}}{\partial x^{2}} \int_{0}^{l} \frac{\mu}{2} \\
& \left.\cdot e^{-\mu|x-\theta|} \frac{\partial^{3} w(\theta, t)}{\partial \theta^{2} \partial t}\right] \\
& -\frac{N}{m}\left[\frac{\partial^{2} w(t, x)}{\partial x^{2}}+\frac{1}{R}\right] \\
& =\frac{q(x, t)}{m}
\end{aligned}
$$

Solution of this equation should respond to the boundary conditions for $\mathrm{x}=0$ and $\mathrm{x}=1$.

Function $w(x, t)$ is searched as eigenvalues of arc vibrations:

$$
w(x, t)=\sum_{i=1}^{n} f_{i}(t) V_{i}(x)
$$

Here $f_{i}(t)$ - generalized displacements, a $V_{i}(x)$ - base functions.

To obtain the generalized displacements $f_{i}(\tau)$ the Galerkin method is used. The resulting system of the integral-differential equations:

$$
\begin{gathered}
\ddot{f}_{j}(\tau)+k_{j}^{4}\left(\frac{E I}{m}\right) f_{j}(\tau) \\
+\gamma \frac{E I}{m a_{j}} \sum_{i=1}^{n} \dot{f}_{l}(\tau) \int_{0}^{l} V_{j}(x) \frac{\partial^{2}}{\partial x^{2}} \int_{0}^{l} C_{v}(\mid x \\
-\theta \mid) V_{i}^{\prime \prime}\left(x^{\prime}\right) d x d x \\
-\frac{N}{m}\left(\int_{0}^{1} \sum_{i=1}^{n} f_{i}(\tau) \frac{1}{l^{2}} V_{i}^{I I}(z) V_{j}(z) d z\right. \\
\left.+\frac{1}{R} \int_{0}^{1} V_{j}(z) d z\right) \\
=\frac{1}{m a_{j}} \sum_{0}^{n} V_{j}(x) q(x, t) d x \\
\text { where } \mathrm{k}_{\mathrm{j}}^{4}=\mathrm{m} \omega_{\mathrm{j}}^{2} / \mathrm{EI}, \\
\mathrm{a}_{\mathrm{j}}=\int_{0}^{\mathrm{l}} \mathrm{V}_{\mathrm{j}}^{2}(\mathrm{x}) \mathrm{dx} .
\end{gathered}
$$

\section{NUMERICAL EXAMPLES}

The arc has the following parameters: span length $5 \mathrm{~m}$, radius of curvature $10 \mathrm{~m}$, stiffness $37,5 \mathrm{t} / \mathrm{m}^{2}$, both ends are fixed. Then the boundary conditions for the both ends are:

$$
\mathrm{w}=\frac{\partial \mathrm{w}}{\partial \mathrm{x}}=0
$$

base functions are [8]:

$$
\begin{aligned}
\mathrm{V}_{\mathrm{i}}(\mathrm{x})=( & \left.\operatorname{shk}_{\mathrm{i}} \mathrm{l}-\operatorname{sink}_{\mathrm{i}} \mathrm{l}\right)\left(\operatorname{chk}_{\mathrm{i}} \mathrm{x}\right. \\
& \left.-\operatorname{cosk}_{\mathrm{i}} \mathrm{x}\right) \\
& -\left(\operatorname{chk}_{\mathrm{i}} \mathrm{l}\right. \\
& \left.-\operatorname{cosk}_{\mathrm{i}} \mathrm{l}\right)\left(\operatorname{shk}_{\mathrm{i}} \mathrm{x}\right. \\
& \left.-\operatorname{sink}_{\mathrm{i}} \mathrm{x}\right)
\end{aligned}
$$

$\mathrm{k}_{\mathrm{i}}$ calculates as the $\mathrm{i}$ root of the characteristic equation $\operatorname{ch}(\mathrm{kx}) \cos (\mathrm{kx})=1$. 
To make the calculation process simpler let's get rid of the second derivative in the third member of the equation (11) using the partial integration. Then the expression (11) will transform to:

$$
\begin{aligned}
& \ddot{f}_{j}(\tau) \quad+\frac{k_{j}^{4}}{k_{1}^{4}} f_{j}(\tau) \\
& +\frac{\gamma \mu l \omega_{1}}{2 a_{j} k_{1}^{4}} \sum_{i=1}^{n} \int_{0}^{1} V_{j}^{I I}(z) \int_{0}^{1} e^{-\mu l|z-y|} V_{i}^{I I}(y)( \\
& -\frac{N}{a_{j} \omega_{1}^{2} m}\left(\int_{0}^{1} \sum_{i=1}^{n} f_{i}(\tau) \frac{1}{1^{2}} V_{i}^{I I}(z) V_{j}(z) d z\right. \\
& \left.+\frac{1}{R} \int_{0}^{1} V_{j}(z) d z\right)=\frac{q(\tau) l^{4}}{a_{j} k_{1}^{4} E I} \int_{0}^{1} V_{j}(z) d z .
\end{aligned}
$$

Here $\mathrm{z}$ and $\mathrm{y}-$ dimensionless coordinates -

$$
\mathrm{z}=\mathrm{x} / \mathrm{l}, \mathrm{y}=\theta / \mathrm{l},
$$

$\tau-$ dimensionless time

$$
\tau=\omega_{1} \mathrm{t}, \omega_{1}^{2}=\mathrm{EIk}_{1}^{4} / \mathrm{m}, \quad 2 \epsilon=\gamma \omega_{1},
$$

$\omega_{1}-\operatorname{arc}$ minimum eigen frequency.

The $f_{i}(\tau)$ values are obtained after solving the system of equation, and arc deflections - after using expression (10).

\subsection{Shallow arc deformation under the static} load.

Shallow arc dynamics has specific features. Under the certain loads and geometry the shallow arc deflection leaps. [9], This phenomenon could be dangerous for the whole structure.

For the further research let's determine the external load that will cause the deflection leap.

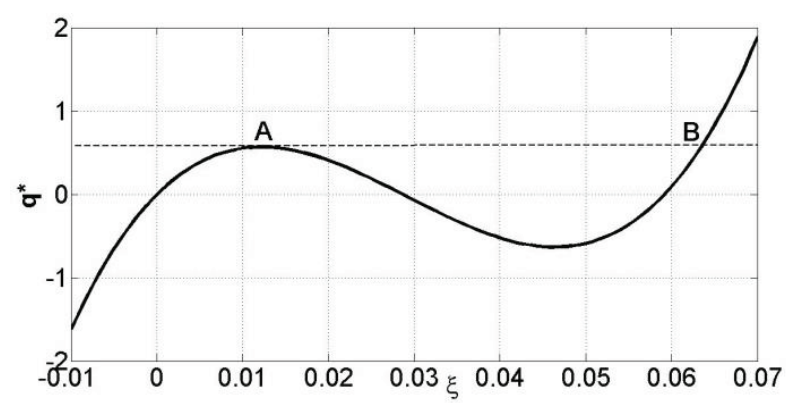

Figure 1. Static deflection curvature for the shallow arc.
In fig. 1 three values of the arc deflection $\xi$ correspond to the one value of parameter $\mathrm{q}^{*}$ which characterize the external load. The deflection increases continuously till the point A on the curvature and then leaps to the point B. This happens when the load value is $119 \mathrm{t}$.

\subsection{Shallow arc vibrations under the periodic load.}

To study the influence of nonlocal damping on the results of shallow arc vibrations modeling consider it's dynamics under the periodic deterministic and stochastic load.

All the necessary programs for solving the of system of equations (14) and determining the deflections and motion velocities in any point of the arc were developed in MATLAB. The arc is vibrating under the load $q=A \cdot \sin (\omega t)$. Here $A$ - is the load amplitude, $\omega$ - the load frequency, which is assumed $\frac{\omega_{1}}{2}$.

For illustrative purposes the system vibrations is presented as the phase diagrams. In dynamics arc vibrates next to one (fig $2 a$ ) or two (fig $2 b$ ) points of equilibrium depending on absence or presence of the deflection leap in statics correspondingly.

a)

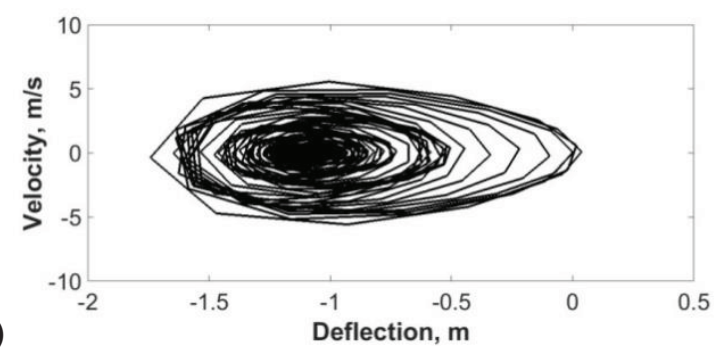

b)

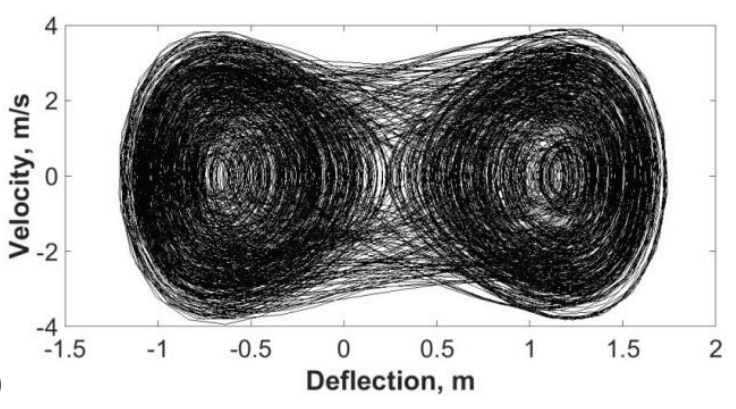

Figure 2. Shallow arc vibrations under the periodic load (phase diagrams)

a) from -620 to -380 $t, b$ ) амплитудой $350 t$. 
For the computer modeling results comparison two histograms of arc deflections in the middle point are obtained considering and not considering nonlocal damping. (Fig. 3).

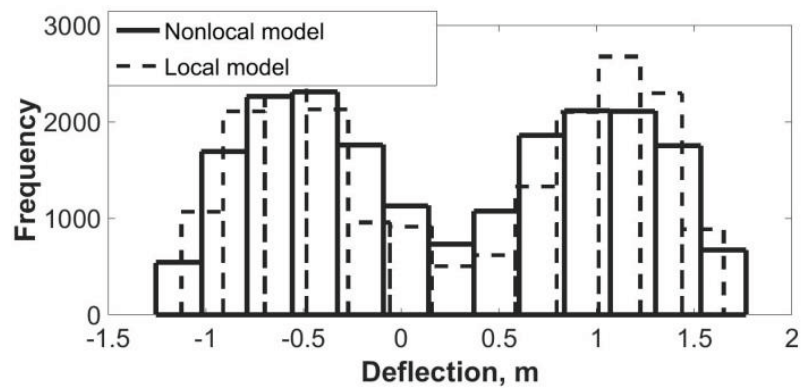

Figure 3. Histograms of deflections for the load amplitude $A=465 t$.

The deflections amplitude decreases when the local model is used. The interesting case is arc vibrations under the load that has an amplitude $140 \mathrm{t}$ (fig. 4). In this case the local model gives a resulting histogram with just one maximum which corresponds to the vibrations next to one point of equilibrium. However the model gives two points of equilibrium when the nonlocal model is used. Hence the regime of shallow arc dynamics totally changes.

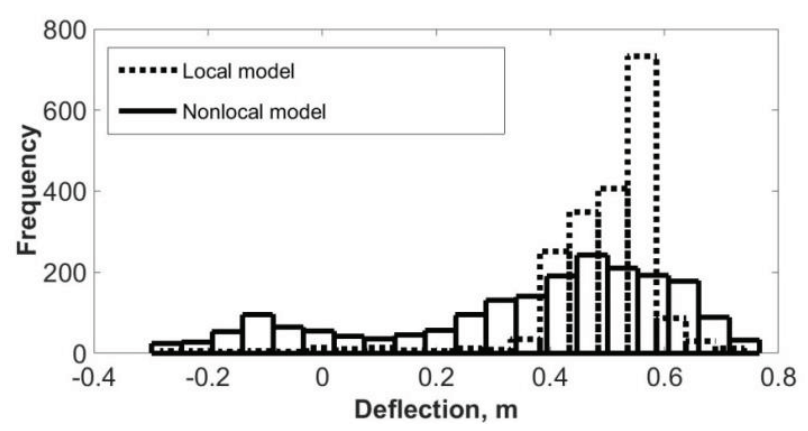

Figure 4. Histograms of deflections for the load amplitude $A=140 t$.

3.3. Shallow arc vibration under the stationary stochastic load.

Let's consider the influence of nonlocal damping on the arc vibration process under the stochastic distributed loads. The load is the random stationary process with the zero mathematical expectation and spectral density:

$$
S(\omega)=\frac{2 \sigma^{2} \cdot \delta\left(\delta^{2}+\theta^{2}\right)}{\pi\left[\left(\omega^{2}-\theta^{2}-\delta^{2}\right)^{2}+4 \delta^{2} \cdot \omega^{2}\right]}
$$

Here $\sigma^{2}-$ variance of random process, $\delta$ and $\theta$ parameters, that characterize the correlation scale and latent frequency of the stochastic load. The method of the canonic expansion [4] is used for modeling the random stationary process. For this purpose the random is presented as:

$$
q(t)=\sum_{k=0}^{n}\left(U_{k} \cos \omega_{k} t+V_{k} \cos \omega_{k} t\right)
$$

Here $\mathrm{U}_{\mathrm{k}}, \mathrm{V}_{\mathrm{k}}$ - uncorrelated normally distributed random values with the zero mathematical expectation and equal variances for each pair of random values with equal indices $k$. To calculate these variances the $\omega$-axis section $2 \mathrm{~L}$ long is selected. The origin is in the middle of the selected section. When $|\omega|>L$ the spectral density could be assumed zero. The whole selected section is devided by the equal parts $\Delta \omega$ long. Then the variance of the random values $U_{k}, V_{k}$ is calculated by the formula:

$$
\mathrm{D}_{\mathrm{k}}=2 \mathrm{~S}\left(\omega_{\mathrm{k}}\right) \cdot \Delta \omega
$$

The random stationary load is Gaussian and permanent along the arc in each moment The correlation function for the load obtained using 400 realizations of the random process is presented on the fig. 5 The solid line is for the theoretical correlation function which was calculated by the formula:

$$
\begin{aligned}
\mathrm{K}\left(\tau_{1}-\tau_{2}\right)= & \sigma^{2} \mathrm{e}^{-\delta\left|\tau_{1}-\tau_{2}\right|}\left[\operatorname { c o s } \theta \left(\tau_{1}\right.\right. \\
& \left.\left.-\tau_{2}\right)+\frac{\delta}{\theta} \sin \theta\left(\tau_{1}-\tau_{2}\right)\right]
\end{aligned}
$$


The dash line is corresponded to the correlation function that was obtained using the numerical modeling data.

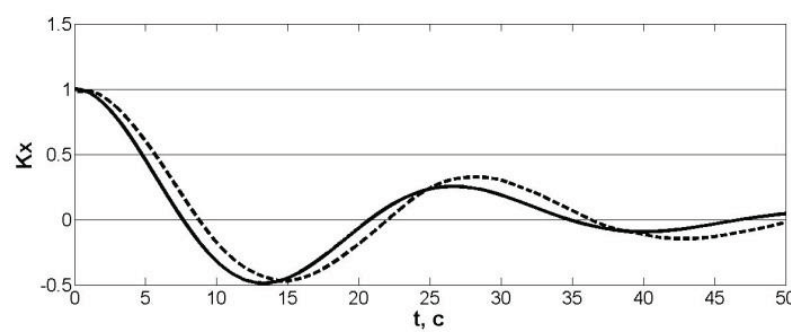

Figure 5. The Correlation Function for the Random Stationary Load.

To compare the local and nonlocal model the arc vibrations modeling results are presented as histograms (fig. 6) 400 realizations of the random process were modelled. The cross section of the procsee is the step \#7700 because at this point the process is already stable.

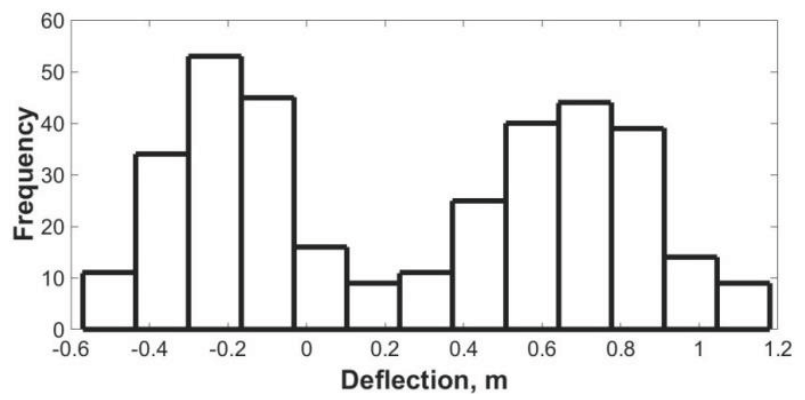

Figure 6. Histograms (Arc Vibrations Modeling Results).

The resulting histogram is bimodal. To analyze the obtained data the histogram was stratified (fig. 7)

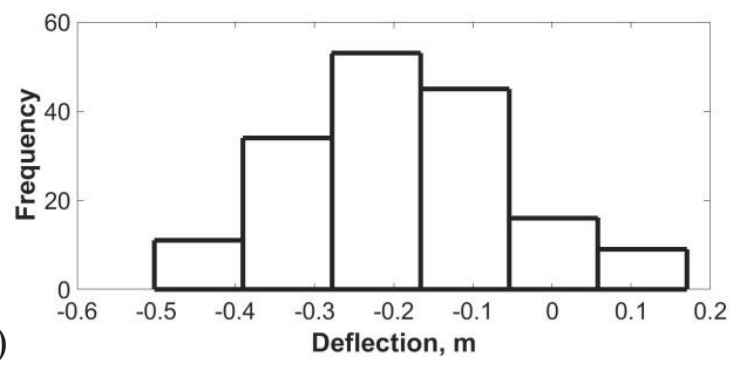

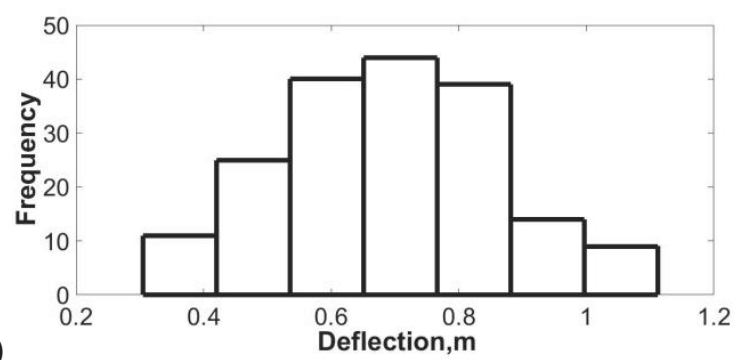

Figure 7. Stratification of the shallow arc deflection histogram a) left part, b) right part.

The both parts were assumed normal. This assumption was verified by Pearson fitting criterion. For the significance level 0,05 for the left part $\chi^{2}=5,02<\chi_{\mathrm{cr}}{ }^{2}=7,81$, and for the right part $-\chi^{2}=4,98<\chi_{\mathrm{cr}}{ }^{2}=9,49$, hence the both parts could be treated like if they were normally distributed.

The histograms were obtained to compare the results for the local and nonlocal model. The arc deflection amplitude is less when the local model is used (fig. 8).

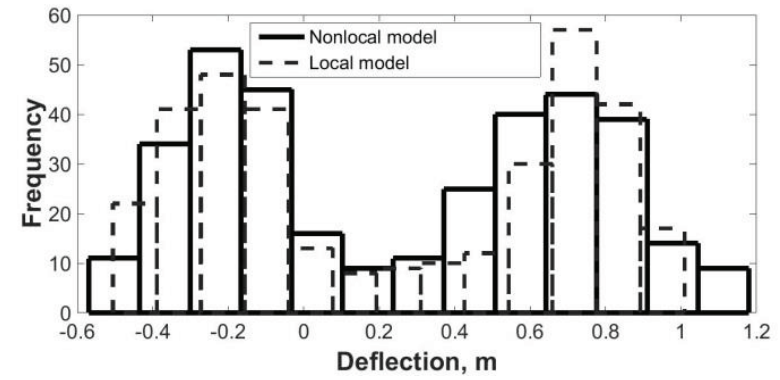

Figure 8. Histograms of arc deflections for the stochastic stationary load.

The confidence intervals are presented in table 1 .

\section{DISCUSSION}

In this paper the nonlocal damping consideration influence on the results of computer modeling of nonlinear systems subjected to periodic deterministic and stochastic stationary loads. The computer model of the arc is developed. Computer modeling consider nonlocal damping in comparison to local model gives increase of shallow arc deflection. In some load cases nonlocal model shows total change of the shallow arc dynamic behavior. 
Моделирование колебаний нелинейных систем с учетом нелокального демпфирования

Table 1. The shallow arc deflection confident intervals.

\begin{tabular}{|c|c|c|c|c|}
\hline \multirow{2}{*}{ Confidence interval } & \multicolumn{3}{|c|}{ Intervals` limits , } \\
\cline { 2 - 5 } & \multicolumn{2}{|c|}{ Nonlocal model } & \multicolumn{2}{c|}{ Local model } \\
\hline \multirow{2}{*}{$68,27 \%$ (from $-\sigma$ to $\sigma$ ) } & $\begin{array}{c}\text { from } 0,3609 \\
\text { to }-0,0288\end{array}$ & $\begin{array}{c}\text { from } 0,4848 \\
\text { to } 0,8901\end{array}$ & $\begin{array}{c}\text { from }-0,3656 \\
\text { to } 0,0342\end{array}$ & $\begin{array}{c}\text { from } 0,4741 \\
\text { to } 0,8083\end{array}$ \\
\hline $95,45 \%$ (from $-2 \sigma$ to $2 \sigma)$ & $\begin{array}{c}\text { from }-0,5270 \\
\text { to } 0,1373\end{array}$ & $\begin{array}{c}\text { from } 0,2821 \\
\text { to } 1,0928\end{array}$ & $\begin{array}{c}\text { from }-0,5312 \\
\text { to } 0,1314\end{array}$ & $\begin{array}{c}\text { from } 0,3069 \\
\text { to } 0,9755\end{array}$ \\
\hline $99,73 \%$ (from $-3 \sigma$ to $3 \sigma$ ) & $\begin{array}{c}\text { from }-0,6931 \\
\text { to } 0,3034\end{array}$ & $\begin{array}{c}\text { from } 0,0794 \\
\text { to } 1,2955\end{array}$ & $\begin{array}{c}\text { from }-0,6969 \\
\text { to } 0,2971\end{array}$ & $\begin{array}{c}\text { from } 0,1398 \\
\text { to } 1,1427\end{array}$ \\
\hline
\end{tabular}

\section{REFERENCES}

1. Banks H.T., Inman D.J. On Damping Mechanisms in Beams. // Journal of Applied Mechanics, 1991, 58 (3), pp. 716723.

2. Lei Y., Friswell M.I., Adhikari S.A. Galerkin Method for Distributed Systems with Non-Local Damping. // International Journal of Solids and Structures, 2006, Volume 43, pp. 3381-3400.

3. Russell D.L. On Mathematical Models for the Elastic Beam with FrequencyProportional Damping. // In: Banks, H.T. (Ed.), Control and Estimation in Distributed Parameter Systems. SIAM, Philadelphia, PA, 1992, pp. 125-169.

4. Ventsel E.S. Teoriya Veroyatnostey [Probability Theory]. Moscow, Vysshaya shkola, 1999, 576 pages.

5. Kalitkin N.N. Chislennie Metodi [Numerical methods]. Saint-Petersburg, BHV-Peterburg, 2011, 592 pages.

6. Potapov V.D. Stability of Rods Under Stochastic Loadind Considering Nonlocal Damping. // Problems of Machinery and reliability, 2012, Vol. 4, pp. 25-31.

7. Potapov V.D. Stability of Stochastic Elastic and Viscoelastic Systems. Chichester, Wiley, 1999.
8. Filippov
A.P.
Kolebaniya
Deformiruyemikh System [Dynamics of

deformable systems]. Moscow, Mashinostroyenie, 1970, 734 pages.

9. Aleksandrov A.V., Potapov V.D. Osnovi Teorii Uprugosti i Plastichnosti [Basics of the elasticity and plasticity theory.]. Moscow, Vysshaya Shkola, 1990, 400 pages.

\section{СПИСОК ЛИТЕРАТУРЫ}

1. Banks H.T., Inman D.J. On Damping Mechanisms in Beams. // Journal of Applied Mechanics, 1991, 58 (3), pp. 716723.

2. Lei Y., Friswell M.I., Adhikari S.A. Galerkin Method for Distributed Systems with Non-Local Damping. // International Journal of Solids and Structures, 2006, Volume 43, pp. 3381-3400.

3. Russell D.L. On Mathematical Models for the Elastic Beam with FrequencyProportional Damping. // In: Banks, H.T. (Ed.), Control and Estimation in Distributed Parameter Systems. SIAM, Philadelphia, PA, 1992, pp. 125-169.

4. Ventsel E.S. Teoriya Veroyatnostey [Probability Theory]. Moscow, Vysshaya shkola, 1999, 576 pages.

5. Kalitkin N.N. Chislennie Metodi [Numerical methods]. Saint-Petersburg, BHV-Peterburg, 2011, 592 pages. 
6. Potapov V.D. Stability of Rods Under Stochastic Loadind Considering Nonlocal Damping. // Problems of Machinery and reliability, 2012, Vol. 4, pp. 25-31.

7. Potapov V.D. Stability of Stochastic Elastic and Viscoelastic Systems. Chichester, Wiley, 1999.

8. Filippov A.P. Kolebaniya Deformiruyemikh System [Dynamics of deformable systems]. Moscow, Mashinostroyenie, 1970, 734 pages.

9. Aleksandrov A.V., Potapov V.D. Osnovi Teorii Uprugosti i Plastichnosti [Basics of the elasticity and plasticity theory.]. Moscow, Vysshaya Shkola, 1990, 400 pages.

Vadim D. Potapov, Professor, Dr.Sc.

Elena S. Shepitko, graduate student, Assistant of the Department "Computer Aided Design Systems", Russian university of transport (MIIT); 127994, Russia, Moscow, 9b9 Obrazcova Street; phone +7(905)756-98-05;

E-mail: shepitko-es@mail.ru.

Потапов Вадим Дмитриевич, профессор, доктор технических наук.

Шепитько Елена Сергеевна, аспирант, ассистент кафедры «Системы автоматизированного проектирования», Российский университет транспорта (МИИТ); 127994, ГСП-4, г. Москва, ул. Образцова, д. 9, стр. 9; тел. +7(905)756-98-05;

E-mail: shepitko-es@mail.ru. 